ACCEPTED VERSION

\title{
Romantic Nostalgia as a Resource for Healthy Relationships
}

\author{
Nicholas D. Evans ${ }^{1}$, Jacob Juhl' ${ }^{2}$, Erica G. Hepper ${ }^{3}$, \\ Tim Wildschut ${ }^{2}$, Constantine Sedikides ${ }^{2}$, and Adam K. Fetterman ${ }^{4}$ \\ ${ }^{1}$ University of Texas at El Paso \\ ${ }^{2}$ University of Southampton \\ ${ }^{3}$ University of Surrey \\ ${ }^{4}$ University of Houston
}

Word Count: 10,564

Corresponding author: Nicholas Evans, Psychology Department, University of Texas at El Paso, 500 W University Ave., El Paso, TX, 79902, USA; Email: ndevans@miners.utep.edu. 


\begin{abstract}
Nostalgia is an emotion that confers psychological benefits. The literature has neglected romantic nostalgia - that is, nostalgia specifically for past experiences shared with one's partner - and its potential advantages for relationships. We examined romantic nostalgia in one correlational study, two experiments, and one daily diary study $(N=638)$. Romantic nostalgia was positively associated with greater relationship commitment, satisfaction, and closeness (Study 1). Additionally, inducing romantic nostalgia via a writing task (Study 2) or music (Study 3) strengthened relational benefits. Finally, participants reported more positive relationshipspecific experiences on days when they felt greater romantic nostalgia (Study 4). We discuss contributions to the nostalgia and relationships literatures.
\end{abstract}

Keywords: Romantic nostalgia, closeness, commitment, relationship satisfaction, romantic relationships 


\section{Romantic Nostalgia as a Resource for Healthy Relationships}

Romantic relationships are vital to psychological wellbeing and physical health (Simpson \& Campbell, 2013), and it is therefore crucial to understand how romantic partners can restore, maintain, and enhance relationship functioning. One potential arrow in their quiver is romantic nostalgia, defined as nostalgia specifically for past experiences shared with one's current romantic partner. Nostalgia, more generally, entails several psychological benefits, including social connectedness and meaning in life (Sedikides et al., 2015). We built on this theoretical and empirical foundation to investigate whether romantic nostalgia brings about relationship-specific benefits.

\section{Romantic Relationships}

Humans have a fundamental need to belong that is met, at least in part, through initiating and maintaining interpersonal bonds, including romantic relationships (Baumeister \& Leary, 1995). Romantic relationships frequently become an integral part of one's self-concept (Aron et

al., 1992, 1995; Mattingly et al., 2020) and confer psychological advantages, including emotional support (Cramer, 2004), affection (Gulledge et al., 2003), and companionship (Sedikides et al., 1994). Romantic relationships greatly impact romantic partners and can enhance the quality of their lives (Braithwaite et al., 2010; Bucher et al., 2019).

The literature has identified several indicators of relationship quality. Closeness (often referred to as intimacy) is the degree to which partners feel bonded to one another (Dibble et al., 2012; Sternberg \& Grajek, 1984). Satisfaction is the level of positive emotions experienced in the relationship (i.e., how happy the relationship makes the partners; Rusbult, 1980, 1983). Finally, commitment is the intent or desire to maintain one's romantic relationship and work toward making the relationship last (Rusbult, 1980, 1983). Closeness, satisfaction, and 
commitment are interrelated indicators of relationship quality (Maxwell, 1985; Rusbult et al., 1998).

The literature has also identified two distinct and positive types of romantic love: compassionate and passionate. Compassionate love is characterized by respect, trust, affection, and care when one's partner is suffering or in need (Sprecher \& Fehr, 2005). Passionate love (also known as the "Eros" love style; Hendrick \& Hendrick, 1986) is characterized by a deep desire or yearning to be with one's romantic partner (Hatfield \& Walster, 1978). Compassionate and passionate love are highly correlated and are additional indicators of relationship quality. Both are associated with higher levels of satisfaction and commitment (Acevedo \& Aron, 2009; Fehr et al., 2014; Lemieux \& Hale, 1999; Neto, 2021; Neto \& Wilks, 2017). Additionally, compassionate love is linked to increased closeness (Fehr et al., 2014) or intimacy (Neto, 2021), and passionate love is linked to greater self-disclosure (Kito, 2005), a key component of closeness (Aron et al., 1997; Sedikides et al., 1999).

To maintain, restore, or enhance relationship functioning, partners deploy various resources, including trust, empathy and perspective-taking, and gratitude for the partner. Researchers have extensively documented the beneficial impact of these relationship maintenance strategies on closeness (Murray \& Hazelwood, 2011), satisfaction (Algoe et al., 2010; Cramer \& Jowett, 2010; Davis \& Oathout, 1987; Franzoi et al., 1985; Schröder-Abé \& Schütz, 2011), and commitment (Gordon et al., 2012). We posit that nostalgia for past experiences shared with one's current romantic partner also improves relationship quality. We begin with a brief exposition to the nostalgia literature.

\section{Nostalgia}


Nostalgia is a "sentimental longing or wistful affection for the past" (The New Oxford Dictionary of English, 1998, p. 1266). Prototype analyses have illustrated that the central features of nostalgia include reminiscence, longing, fond and rose-colored memories, happiness and enjoyment, as well as desire to re-live to the past. Narrative analyses have revealed that, when nostalgic, people commonly recall meaningful life events (family re-unions, graduations, weddings), time periods (e.g., childhood, college), and places (e.g., grandma's house, vacation resort); moreover, in nostalgic narratives, people nearly always place themselves among close others (family, friends; Abeyta et al., 2015; Wildschut, Sedikides, Arndt, \& Routledge, 2006). Further, multidimensional scaling analyses have revealed that nostalgia is a positively valenced, approach-oriented, and low arousal emotion (Van Tilburg et al., 2018). Although nostalgia is largely positive, nostalgic reverie is frequently bittersweet: It can contain traces of sadness, as people desire to re-experience the past (Madoglou et al., 2017; Sedikides \& Wildschut, 2016).

Nostalgia bears several psychological benefits. For example, it strengthens a sense of meaning in life (Sedikides \& Wildschut, 2018), optimism (Cheung et al., 2013), self-continuity (Sedikides et al., 2016), positive self-regard (Vess et al., 2012), and social connectedness (Frankenbach et al., 2021). Additionally, nostalgia is a psychological resource to which people turn when they face psychological adversity (Routledge et al., 2013; Wildschut \& Sedikides, 2022). For example, meaninglessness (Routledge et al., 2011), death thoughts (Juhl et al., 2010), and loneliness (Zhou et al., 2008) increase nostalgia.

\section{Romantic Nostalgia}

As mentioned, people are nostalgic for many aspects from their past (e.g., events, time periods, places). One of the most frequent targets of nostalgic reflection is others: friends, family, and romantic partners (Abeyta et al., 2015; Madoglou et al., 2017). In this article, we put a 
microscope on nostalgia, focusing on past experiences that are shared with one's current romantic partner - that is, romantic nostalgia. Just as nostalgia in general (henceforth, referred to as general nostalgia), ${ }^{1}$ bears psychological benefits (e.g., meaning in life, social connectedness), so does romantic nostalgia have relationship-specific benefits.

The rationale for this proposal is as follows. First, general nostalgia, which largely contains thoughts about others, increases perceptions of connectedness with others (Frankenbach et al., 2021). It stands to reason that romantic nostalgia, which entails directly reflecting on one's romantic partner, should similarly increase perceptions of closeness with one's romantic partner. Second, general nostalgia elevates perceived meaning in life (Routledge et al., 2011). In the same vein, romantic nostalgia should elevate the perceived meaningfulness and value that partners place on their romantic relationship. Third, when nostalgic, people primarily ponder positive events often through rose-colored glasses (Wildschut et al, 2006). They may also ponder ambivalent events, but the relevant narratives typically follow a redemption sequence (McAdams et al., 2001) whereby initial adversity gives way to increased positivity and a happy ending (e.g., life lessons learned; Wildschut et al., 2006). Thus, when experiencing romantic nostalgia, it is likely that partners focus on positive relationship experiences or frame relationship experiences in a redemptive trajectory. This should, in turn, increase relationship closeness, satisfaction, and commitment. Finally, nostalgizing about one's romantic relationship may heighten the accessibility of one's investment into their relationship. According to the investment model of relationships (Rusbult, 1980), greater relationship investment strengthens relationship commitment.

\footnotetext{
${ }^{1}$ We do not advocate the use of the term general nostalgia outside the context of this article. We only use it here for clarity.
} 
The literature provides indirect evidence for our proposal that romantic nostalgia improves perception of relationship quality. For example, people who enjoy telling the story of their romantic relationships and view the course of their relationships as a coherent narrative report higher relationship satisfaction (Dunlop, 2019). Indeed, those who mention emotionally positive experiences when telling the story of their romantic relationship, evince greater relationship satisfaction (Dunlop, 2020). Also, those who discuss intimate topics with their partner while telling stories of relationship events report greater relationship satisfaction and closeness, and fewer thoughts of breaking up (Frost, 2013). In somewhat more direct evidence for our proposal, when recalling relationship-defining memories, people experience an enhanced sense of intimacy, commitment, and relationship satisfaction (Alea \& Bluck, 2007; Alea \& Vick, 2010; Guilbault \& Philippe, 2017).

Yet, direct evidence on romantic nostalgia is scarce. Muise et al. (2020) investigated sexual nostalgia. On the surface, sexual nostalgia might be considered a subtype of romantic nostalgia, as sexual experiences frequently occur with romantic partners. However, the authors defined sexual nostalgia as "reflection on positive sexual experiences with past partners" (italics added, p. 1538), and found that it occurs among people with unmet sexual needs in their current relationships. Perhaps most directly relevant to our proposal, Mallory et al. (2018) developed a self-report measure of romantic nostalgia and examined its association with indices of relationship functioning in two studies. Their findings were mixed and difficult to interpret. Cross-sectional Study 1 tested college students who were in an exclusive dating relationship. Romantic nostalgia was positively associated with relationship satisfaction but negatively associated with benign attributions about one's partner. Longitudinal Study 2 tested college students involved in committed relationships. They completed measures of romantic nostalgia 
and relationship satisfaction at three time points. In cross-lagged analyses, Time 1 relationship satisfaction predicted decreased romantic nostalgia at Time 2, and Time 1 romantic nostalgia predicted decreased relationship satisfaction at Time 2. Inconsistent with our proposal, these findings suggest a negative reciprocal relationship between romantic nostalgia and relationship satisfaction. Yet, analysis of Time 3 data failed to replicate these results. Interpretation of these findings is further clouded by the assessment of romantic nostalgia. Participants rated the degree to which they missed various aspects of the early parts of their relationship with their current partner (e.g., "Times when this person made you laugh," "Times you spent talking with this person"; 1 = do not miss at all, 5 = miss very much/very frequently). Endorsement of these items implies a sense of loss or relationship deterioration, and, although "missing" is a prototypical feature of nostalgia, it is not a highly central one (Hepper et al., 2012, 2014). Therefore, the focus of these items is on the relatively narrow negative scope of nostalgia, rather than the more prominent positive experience of the emotion (Hepper et al., 2021; Layous et al., 2021). In addition, the correlational nature of both studies limits causal inferences. In summary, there is solid ground to expect that romantic nostalgia improves perceptions of relationship quality. We turn to an examination of this proposal.

\section{Overview}

In four studies, we examined correlates and benefits of romantic nostalgia, capitalizing on validated measures and experimental manipulations from the nostalgia literature. Our investigation focused on perceptions of relationship quality — an important facet of actual relationship quality (Maxwell, 1985; Rusbult et al., 1998). In Study 1, we tested associations between self-reported romantic nostalgia and indicators of relationship quality (i.e., closeness, satisfaction, commitment). In Studies 2 and 3, we assessed the causal effect of romantic 
nostalgia — induced via writing and music, respectively—on perceived relationship quality.

Lastly, in Study 4, we examined romantic nostalgia in daily life. We offer specific hypotheses in each study's introduction. We provided complete stimulus materials in Supplementary Material and deposited all data at https://tinyurl.com/e4x8p4zy. ${ }^{2}$

\section{Study 1}

Study 1 served as an empirical foray into the correlates of romantic nostalgia. We measured romantic nostalgia as well as perceived relationship closeness, commitment, and satisfaction - three of the six components of relationship quality (Fletcher et al., 2000). We hypothesized that self-reported romantic nostalgia would be positively associated with relationship closeness, satisfaction, and commitment. ${ }^{3}$

\section{Method}

\section{Participants}

We recruited 251 MTurk workers from the United States, who participated in exchange for $\$ 0.50$. Participants had to be at least 18 years old and currently in a romantic relationship. To determine sample size, we relied on Schönbrodt and Perugini (2013), who found that correlations between $r=.1$ and $r=.2$ stabilize between 238 and 252 participants. Therefore, we aimed for 250.

\footnotetext{
${ }^{2}$ We preregistered Studies 1 and 3 on the Open Science Framework. The preregistration for Study 1 can be accessed at https://tinyurl.com/wzy4xazb. The preregistration for Study 3 can be accessed at https://tinyurl.com/tmwr29jf.

${ }^{3}$ We deviated from the preregistered hypotheses and analysis plan. After consultation with the research team, we omitted one variable, conflict compromise, because its relevance to the current investigation was unclear. Originally, we hypothesized that romantic nostalgia would be associated with closeness, satisfaction, and commitment, above and beyond conflict compromise. Therefore, as we omitted conflict compromise, we simply assessed the bivariate associations between romantic nostalgia and the three putative relational benefits. Nevertheless, when controlling for conflict compromise, romantic nostalgia significantly correlated with closeness, $r(244)=.22, p<.001$, and relationship satisfaction, $r(244)=.19$, $p=.002$, but not commitment, $r(244)=.11, p=.102$.
} 
We removed from analyses four participants who were not currently in a romantic relationship and two participants for inattentive responding. The final sample comprised 245 participants (127 cisgender men, 116 cisgender women, 2 nonbinary; age: $M=32.38$ years, $S D=$ 9.10 years; relationship duration: $M=82.93$ months, $S D=92.34$ months; $75.5 \%$ White, $11.0 \%$ Hispanic/Latinx, 10.2\% Asian American/Pacific Islander, 6.9\% Black/African American, 3.0\% Native American, 0.4\% Arab American ${ }^{4}$ ). A sensitivity analysis (G*Power 3.1; Faul et al., 2013) indicated that our sample size allowed us to detect small-to-medium effects $(r=.13)$ with acceptable power of $(1-\beta)=.80$ at $\alpha=.05$ (two-tailed).

\section{Materials and Procedures}

Participants completed the key measures of romantic nostalgia, closeness, satisfaction, and commitment in random order.

Romantic Nostalgia. To measure romantic nostalgia, we adapted items from the 7 -item Southampton Nostalgia Scale (Sedikides et al., 2015). Although the original Southampton Nostalgia Scale assesses the importance of nostalgia to participants as well as the frequency with which they experience nostalgia, it was recently shown to be unidimensional (Biskas et al., 2021). Even so, we additionally tested and confirmed the satisfactory model fit of the singlefactor structure model for the adapted romantic nostalgia measure (see Supplementary Material for model fit indices and factor loadings). Participants read a definition of nostalgia ("a sentimental longing for the past") and responded to the seven items, modified such that each referred to romantic nostalgia. The items assessed the importance that participants placed on romantic nostalgia (e.g., "How valuable is romantic nostalgia to you?") and the frequency with which they experienced romantic nostalgic (e.g., "How often do you experience nostalgia about

\footnotetext{
${ }^{4}$ For all studies, participants were given the option to select any and all ethnicity/race options with which they identify. Therefore, the sum of the percentages for race/ethnicity categories exceeds $100 \%$.
} 
your romantic partner and/or romantic relationship?"; $1=$ not at all, 7 = very much). Thus, departing from Mallory et al. (2018), our measure did not focus exclusively on the early parts of participants' relationships and did not ask participants to rate how much they "miss" those experiences. We averaged responses to compute romantic nostalgia scores $(M=4.40, S D=1.47$, $\alpha=.93)$.

Relationship Closeness. To measure closeness, we used the 11-item Unidimensional Relationship Closeness Scale (Dibble et al., 2012; e.g., "My relationship with my romantic partner is close;" 1 = strongly disagree, 7 = strongly agree $)$. We averaged responses to calculate relationship closeness scores $(M=5.91, S D=1.02, \alpha=.94)$.

Relationship Satisfaction. We used the Satisfaction subscale of the Investment Model Scale (Rusbult et al., 1998) to measure relationship satisfaction. Participants indicated the extent to which they agreed with five items (e.g., "I feel satisfied with our relationship;" $1=$ strongly disagree, 7 = strongly agree . We averaged responses to compute relationship satisfaction scores $(M=5.60, S D=1.20, \alpha=.90)$.

Relationship Commitment. We assessed relationship commitment with the Commitment facet of the Investment Model Scale (Rusbult et al., 1998). Participants indicated the extent to which they agreed with seven items (e.g., "I want our relationship to last for a very long time;" 1 = strongly disagree, 7 = strongly agree . We averaged responses to compute relationship commitment scores $(M=5.85, S D=1.19, \alpha=.86)$.

\section{Results and Discussion}

We tested the associations between romantic nostalgia and the putative relational benefits (Table 1). As hypothesized, romantic nostalgia positively correlated with closeness, satisfaction, and commitment. Prior work demonstrated a link between relationship length and commitment 
(Rusbult et al., 1998). Relationship length may therefore confound the association between romantic nostalgia and the benefits. Indeed, relationship length positively correlated with commitment. However, it did not significantly correlate with romantic nostalgia. Nevertheless, we computed partial correlations between romantic nostalgia and benefits, controlling for relationship length. These partial correlations showed that romantic nostalgia positively correlated with closeness, $r(244)=.24, p<.001$, satisfaction, $r(244)=.21, p<.001$, and commitment, $r(244)=.17, p=.010$.

Study 1 provided initial support for an association between romantic nostalgia and benefits: Partners who were more romantically nostalgic reported greater closeness, satisfaction, and commitment. However, given that we measured rather than manipulated romantic nostalgia, we could not make claims about its causal influence on relational benefits. We addressed this limitation in Study 2.

\section{Study 2}

To test the causal effects of romantic nostalgia, we experimentally induced it and measured ensuing relational benefits. We hypothesized that romantic nostalgia (vs. control) would bolster perceived relationship closeness, satisfaction, and commitment.

\section{Method}

\section{Participants}

We determined the sample size for Study 2 by conducting a power analysis $\left(\mathrm{G}^{*}\right.$ Power; Faul et al., 2013). Previous research has indicated that nostalgia manipulations produce medium effect sizes (Evans et al., 2021; Juhl et al., 2021; Sedikides et al., 2015). Our power analysis revealed that the minimum sample size to detect an effect size of $f=.25$ at power $=.80$ and $\alpha=$ .05 (two-tailed) was 128 . We initially recruited 186 students from a large Southwestern 
university in the United States (for course credit), anticipating attrition. We removed the data of 18 participants who were not involved in a romantic relationship at the time of the study and 34 participants who did not complete the manipulation task (e.g., wrote nothing) or the dependent measures. The final sample consisted of 134 participants (98 women, 36 men; $M=20.31$ years, $S D=3.22$ years; $91.8 \%$ Hispanic/Latinx, $11.9 \%$ White, $2.2 \%$ Black/African American, 2.2\% Asian American/Pacific Islander, 0.7\% Middle Eastern, 0.7\% unspecified Multi-ethnic/Multiracial). ${ }^{5}$

\section{Procedures}

We administered the experiment on Qualtrics, which participants were able to complete on their own time. Participants first filled out a demographics questionnaire. Next, they were randomly assigned to the romantic nostalgia $(n=57)$ or control $(n=77)$ condition. Subsequently, they responded to a manipulation check and the relationship closeness, commitment, and satisfaction scales. ${ }^{6}$

\section{Materials}

Romantic Nostalgia Induction. The Event Reflection Task, for which participants reflect on and write about either a nostalgic or ordinary autobiographical memory, is the most commonly used technique to induce nostalgia (Leunissen et al., 2021; Sedikides et al., 2015). We adapted this technique to elicit romantic nostalgia. In the romantic nostalgia condition, we first provided the formal definition of nostalgia (The New Oxford Dictionary of English, 1998). We then instructed participants to reflect on a nostalgic experience with their current romantic partner, and to write about it for three minutes. We instructed those in the control condition to

\footnotetext{
${ }^{5}$ Due to experimenter error, we did not assess relationship duration in Study 2.

${ }^{6}$ Participants also completed a measure assessing social connectedness. The measure does not specifically pertain to romantic relationships. We present relevant results in Supplementary Material.
} 
reflect on an ordinary experience with their current romantic partner, and to write about it for three minutes. Subsequently, participants automatically progressed to the manipulation check.

Manipulation Check. Participants responded to two statements (i.e., "Right now, I am feeling quite nostalgic," "Right now, I'm having nostalgic feelings") gauging their levels of felt nostalgia $(1=$ strongly disagree, $5=$ strongly agree $)$. We averaged responses to produce manipulation check scores $(M=3.96, S D=1.09, r=.86)$.

Closeness. Participants then completed the Unidimensional Relationship Closeness Scale described in Study 1 (Dibble et al., 2012; $M=6.26, S D=0.75, \alpha=.92$ ).

Satisfaction and Commitment. Finally, participants filled out the Satisfaction $(M=$ 5.95, $S D=0.99, \alpha=.87)$ and Commitment $(M=5.97, S D=0.97, \alpha=.81)$ facets of the Investment Model Scale described in Study 1 (Rusbult et al., 1998).

\section{Results and Discussion}

\section{Preliminary Analyses}

We expected the dependent variables (i.e., closeness, satisfaction, commitment) to be intercorrelated. Indeed, this was the case. Closeness correlated significantly with satisfaction, $r(129)=.70, p<.001$, and commitment $r(128)=.77, p<.001$; satisfaction correlated significantly with commitment, $r(131)=.63, p<.001$. To test the effectiveness of the manipulation, we conducted a one-way (romantic nostalgia vs. control) Analysis of Variance (ANOVA) on the manipulation check. As intended, participants in the romantic nostalgia condition $(M=4.32, S D=0.82)$ felt more nostalgic than those in the control condition $(M=$ $3.69, S D=1.18), F(1,132)=11.84, p<.001, \eta^{2}=.082,90 \%$ CI $[.023, .165] .^{7}$

\section{Effects of Romantic Nostalgia}

\footnotetext{
${ }^{7}$ We report $90 \%$ confidence intervals for $\eta^{2}$, because the $F$-test is one-sided (Steiger, 2004).
} 
To test the effects of romantic nostalgia on closeness, satisfaction, and commitment, we conducted a one-way (romantic nostalgia vs. control) ANOVA on each. Participants in the romantic nostalgia condition felt somewhat closer (although this difference was not statistically significant), reported greater relationship satisfaction, and felt more committed to their partners than those in the control condition (Table 2). In all, Study 2 demonstrated that romantic nostalgia confers relational benefits.

\section{Study 3}

In Study 3, we sought to replicate and extend Study 2 findings by using a different technique to manipulate romantic nostalgia. Research has established that music is a potent nostalgia trigger (Barrett et al., 2010; Cheung et al., 2013; Stephan et al., 2015). Thus, in the present study, we induced romantic nostalgia through songs that hold nostalgic significance to participants' romantic relationships.

As in Study 2, we measured closeness, satisfaction, and commitment after the romantic nostalgia induction. However, we also intended to examine whether romantic nostalgia confers other putative benefits. In particular, we tested whether romantic nostalgia augments connectedness to one's romantic partner (i.e., romantic connectedness) and boosts optimism regarding the future of one's relationship (i.e., relationship optimism). We considered romantic connectedness an additional measure of relationship closeness. Relationship optimism is a component of relationship commitment; it reflects a long-term orientation toward one's relationship and the sense that a relationship will be sustained over time (Arriaga \& Agnew, 2001; Rusbult \& Buunk, 1993).

Additionally, we assessed the two distinct types of romantic love: compassionate (Sprecher \& Fehr, 2005) and passionate (Hatfield \& Walster, 1978). Although these types of 
love are often measured as more stable characteristics, both can be assessed as states that ebb and flow based on external influences (Hatfield \& Sprecher, 1986; Sprecher \& Fehr, 2005). They map respectively onto the love and passion components of relationship quality, meaning that Study 3 covered five of the six components (Fletcher et al., 2000). We hypothesized that participants who listened to a romantically nostalgic song (vs. control: non-nostalgic song) would experience stronger closeness, satisfaction, commitment, romantic connectedness, relationship optimism, compassionate love, and passionate love.

\section{Method}

\section{Participants}

We determined the minimal sample size $(N=172)$ based on the same effect size as Study $2(f=.25)$ at power $=.90$ and $\alpha=.05$ (two-tailed). However, due to COVID-19, we could only recruit 151 students (earning course credit) from a large Southwestern university in the United States before all studies were shut down. All participants were currently in romantic relationships (124 cisgender women, 27 cisgender men; age: $M=21.43$ years, $S D=4.30$ years; relationship duration: $M=29.83$ months, $S D=27.75$ months; $93.4 \%$ Hispanic/Latinx, $25.8 \%$ White, $1.3 \%$ Black/African American, 0.6\% Native American, 0.6\% Middle Eastern). Due to our lower than desired sample size, we conducted a sensitivity analysis (G*Power 3.1; Faul et al., 2013), which indicated that our sample size allowed us to detect small-to-medium effects $(f=.23)$ with acceptable power of $(1-\beta)=.80$ at $\alpha=.05$ (two-tailed), matching Study 2's power.

\section{Procedure and Materials}

Romantic Nostalgia Music Induction. We randomly assigned participants either to a romantic nostalgia $(n=75)$ or control $(n=76)$ condition. In the romantic nostalgia condition, we first provided the formal definition of nostalgia. Then, we asked participants to think of a song 
that reminded them of their romantic relationship and made them feel nostalgic. In the control condition, we asked participants to think of a song they enjoyed and was unrelated to their romantic relationship. In both conditions, we instructed participants to write the name of the song and the artist who performs it on a sheet of paper next to the computer, and notify the experimenter. The experimenter opened Spotify® and cued up each participant's song. Participants then listened to the entire song on Sennheiser headphones.

Manipulation Check. Participants completed the same two-item manipulation check as in Study 3, indicating their response using a slider $(0=$ strongly disagree, $100=$ strongly agree; $M=61.67, S D=33.09, r=.91)$.

Closeness. Participants completed the Unidimensional Relationship Closeness Scale as in Studies 1 and 2 (Dibble et al., 2012) using a slider ( $0=$ strongly disagree, $100=$ strongly agree $)$. We averaged responses to create an index of relationship closeness $(M=88.04, S D=12.38, \alpha=$ $.89)$.

Satisfaction and Commitment. Participants filled out the Investment Model Scale as in Studies 1 and 2 (Rusbult et al., 1998), using a slider ( $0=$ strongly disagree, $100=$ strongly agree $)$, to assess satisfaction $(M=84.76, S D=15.27, \alpha=.85)$ and commitment $(M=88.93, S D$ $=14.82, \alpha=.85)$.

Romantic Connectedness and Relationship Optimism. We adapted prior measures of social connectedness (Wildschut et al., 2006) and optimism (Cheung et al., 2013) to assess romantic connectedness (e.g., "With this song in mind, I feel connected to my romantic partner") and relationship optimism (e.g., "With this song in mind, I feel optimistic about my future with my romantic partner"). For each measure, participants indicated their agreement with four statements using a slider $(0=$ strongly disagree, $100=$ strongly agree $)$. We averaged responses 
to compute romantic connectedness $(M=60.98, S D=38.16, \alpha=.97)$ and relationship optimism $(M=65.36, S D=35.04, \alpha=.96)$ scores.

Compassionate Love. Participants filled out the Compassionate Love Scale (Sprecher \& Fehr, 2005). They indicated their agreement with 21 statements (e.g., "I feel considerable compassionate love for my romantic partner”) using a slider $(0=$ strongly disagree, $100=$ strongly agree $)$. We averaged responses to compute compassionate love scores $(M=87.66, S D=$ $10.58, \alpha=.90)$

Passionate Love. Participants completed the shortened version of the Passionate Love Scale (Hatfield \& Sprecher, 1986). They indicated their agreement with 15 statements (e.g., "For me, my romantic partner is perfect") $)$ using a slider $(0=$ not at all true, $100=$ definitely true $)$. We averaged across responses to compute passionate love scores $(M=76.30, S D=15.60, \alpha=.88)$.

\section{Results and Discussion}

\section{Preliminary Analyses}

All variables were intercorrelated, with the exception of romantic connectedness and commitment (Table 3). To test the effectiveness of the manipulation, we conducted a one-way (romantic nostalgia vs. control) ANOVA on the manipulation check. As intended, participants in the romantic nostalgia condition $(M=81.51, S D=19.38)$ felt more nostalgic than those in the control condition $(M=41.84, S D=32.11), F(1,148)=83.87, p<.001, \eta^{2}=.362,90 \%$ CI $[.264$, $.450]$.

\section{Effects of Romantic Nostalgia}

To test the influence of romantic nostalgia on relational benefits, we conducted a series of one-way ANOVAs (romantic nostalgia vs. control; Table 4). As hypothesized, participants in the romantic nostalgia (vs. control) condition reported higher levels of romantic connectedness, 
relationship optimism, closeness, satisfaction, compassionate love, and passionate love. Those in the romantic nostalgia condition also reported higher commitment than those in the control condition, although this difference was not statistically significant. Taken together, the Study 3 findings replicated and extended those of Study 2 using a different romantic nostalgia induction, and so adding support to the hypothesis that romantic nostalgia strengthens perceptions of relationship quality. ${ }^{8}$

\section{Study 4}

In Study 1, we showed that romantic nostalgia is prognostic of better relationship quality, and, in Studies 2-3, we provided evidence for the causal role of romantic nostalgia in producing these relational benefits. In Study 4, we used a daily diary design to examine the link between romantic nostalgia and relationship functioning in daily life. As in Study 3, we assessed romantic connectedness and relationship optimism. Unique to this study, we were also concerned with a behavioral intention indicative of relationship (dis)satisfaction. Specifically, we assessed participants' desire to leave their romantic partner. We also assessed, as a control variable, the amount of time participants spent time with their romantic partners. We hypothesized that, when controlling for time spent with one's romantic partner, daily romantic nostalgia would be positively associated with romantic connectedness and relationship optimism, and negatively associated with the desire to leave one's romantic partner. ${ }^{9}$

\section{Method}

\section{Participants}

\footnotetext{
${ }^{8}$ Given that listening to music can evoke positive affect (Koelsch, 2013), we re-analyzed our data controlling for overall positive affect. All effects remained significant.

${ }^{9}$ Study 4 involved a time-intensive protocol; for efficiency, we included several items to test hypotheses unrelated to the current investigation as well as participants uninvolved in romantic relationships. Results pertinent to these other items were reported in a recently published article (Evans et al., 2021), which does not mention any of the variables measured and tested in Study 4.
} 
We followed the sampling plan of prior investigations that have used similar daily diary designs (Fetterman et al., 2018; Lenton et al., 2016); that is, we aimed to collect data from approximately 100 participants, a typical sample size used in daily diary research (Ohly et al., 2010). Accordingly, we collected data from 108 students from a large Southwestern university in the United States ( 86 cisgender women, 22 cisgender men; age: $M=20.46$ years, $S D=3.65$ years; 90.7\% Hispanic/Latinx, 26.9\% White, 0.9\% Black/African American, 1.9\% Asian American/Pacific Islander, 0.9\% Native American), all of whom were currently in a romantic relationship (duration: $M=29.58$ months, $S D=33.87$ months). All participants, who earned extra course credit, completed at least one daily survey (out of a possible 14). On average, they completed 9.89 daily surveys, producing 1068 observations.

\section{Materials and Procedures}

We advertised the study for one week. Upon signing up, participants filled out an initial assessment, which comprised several individual difference measures and a demographic questionnaire. ${ }^{10}$ Then, they completed the same daily survey for 14 days, starting the Monday after the recruitment week. Participants received an email at 5:00 p.m. on each of these 14 days. This email contained a link to that day's survey, which was available until 3:00 a.m. the next morning. We randomized the daily items every day for each participant.

We measured each daily construct with a single, face-valid item. For romantic nostalgia, participants responded to the item: "Today, I thought back to a special time with my romantic partner" ( 1 = strongly disagree, $4=$ strongly agree $; M=2.80, S D=1.09)$. For romantic

\footnotetext{
${ }^{10}$ Within the initial assessment, participants also completed the romantic relationship adaptation of the Southampton Nostalgia Scale (Sedikides et al., 2015) used in Study 1 as an individual difference measure of romantic nostalgia $(M=4.90, S D=1.35, \alpha=.93)$. An exploratory analysis revealed that trait romantic nostalgia positively predicted daily romantic nostalgia, $b=.096, t(105)=2.04, p=.043,95 \%$ CI $[.002$, $.190]$.
} 
connectedness, participants rated the item: "Today, I felt connected to my romantic partner" $(1=$ not at all, $4=$ very much; $M=2.93, S D=1.09)$. We assessed relationship optimism with the item: "Today, I felt optimistic about my romantic relationship" $(1=$ not at all, $4=$ very $m u c h ; M$ $=3.02, S D=1.05)$. Desire to leave their romantic partner was captured by the item: "Today, I considered leaving my romantic partner" ( 1 = strongly disagree, $4=$ strongly agree $; M=1.53$, $S D=0.95)$. Finally, to index time spent with their partner, participants responded to the item: “Today, I spent time with my romantic partner" $(1=$ not at all, $4=$ very much; $M=2.48, S D=$ $1.22)$.

\section{Results}

To test our hypotheses concerning the within-person (i.e., daily) associations, we employed a multi-level modeling (MLM) approach (Raudenbush \& Bryk, 2002). This approach allowed us to distinguish within-person from between-person sources of variance (Enders \& Tofighi, 2007). We used the "lme" function within the "nlme" package (Pinheiro et al., 2020) in R. In addition to our fixed effects, we included corresponding random effects to specify standard errors regarding our Level 1 (within-subject) predictors (Barr et al., 2013). To account for individual differences in daily experiences of romantic nostalgia and amount of time spent with romantic partners, we centered these two variables around each person's mean scores (Enders \& Tofighi, 2007). Moreover, the analyses included a first-order autoregressive error structure to account for similarities between adjacent days. We tested the unique link between daily romantic nostalgia and, respectively, daily romantic connectedness, daily relationship optimism, and daily desire to leave, with and without controlling for time spent with one's romantic partner each day. Therefore, we tested two models for each daily relationship outcome:

\section{Model 1:}




$$
\begin{gathered}
y_{i j}=\beta_{0 j}+\beta_{1 j}(\text { Romantic Nostalgia })+r_{i j} \\
\beta_{0 j}=\gamma_{00}+u_{0 j} \\
\beta_{1 j}=\gamma_{10}+u_{1 j}
\end{gathered}
$$

Model 2:

$$
\begin{gathered}
y_{i j}=\beta_{0 j}+\beta_{1 j}(\text { Time Spent with Partner })+\beta_{2 j}(\text { Romantic Nostalgia })+r_{i j} \\
\beta_{0 j}=\gamma_{00}+u_{0 j} \\
\beta_{1 j}=\gamma_{10}+u_{1 j} \\
\beta_{2 j}=\gamma_{20}+u_{2 j}
\end{gathered}
$$

We present the results of these analyses in Table 5. Daily romantic nostalgia uniquely predicted each daily relationship benefit. More precisely, on days that participants felt more romantically nostalgic, they also felt more connected to their romantic partner, more optimistic about their relationship, and less inclined to leave their romantic partner-above and beyond the amount of time they spent with their romantic partners. The Study 4 findings demonstrate, with high ecological validity, that romantic nostalgia is linked to relational benefits in daily life.

\section{General Discussion}

We examined, in four studies, whether romantic nostalgia conveys relational benefits. In Study 1 , we showed that romantic nostalgia is positively associated with perceived closeness, satisfaction, and commitment. In the next two studies, we experimentally induced romantic nostalgia, via written narratives (Study 2) and music (Study 3), to test its causal effect on relational benefits. In Study 2, romantic nostalgia strengthened closeness, satisfaction, and commitment. In Study 3, romantic nostalgia had similar effects on closeness and satisfaction (but not on commitment), while also augmenting perceptions of romantic connectedness, relationship optimism, compassionate love, and passionate love. These effects remained significant after 
controlling for positive affect, demonstrating that the benefits of romantic nostalgia are more than simple positivity. In Study 4, we conceptually replicated these findings in an ecologically valid context. On days when participants reported feeling more nostalgic for their relationship, they also reported stronger connectedness to their partner, greater optimism about the future of their relationship, and a weaker intention to terminate their relationship. These associations remained significant when controlling for the time participants spent with their romantic partner throughout the day.

\section{Implications}

Our research fits within and expands on the nostalgia literature. Prior work has shown that general nostalgia fosters social bonds (Frankenbach et al., 2021; Sedikides \& Wildschut, 2019). However, the relevance of romantic nostalgia for specific close relationships has been relatively unexplored. The results highlight romantic nostalgia's positive role in close relationships. Our findings, therefore, point to new empirical directions regarding relationshipspecific benefits of romantic nostalgia. For example, given that romantic nostalgia promoted compassionate love (Study 3), it might increase empathy (cf. Juhl et al., 2020) and motivate helping of one's romantic partner (Sprecher \& Fehr, 2005). Romantic nostalgia may also serve as a resource to buffer relationship threats: it might help partners maintain intimacy and commitment when they are separated for long periods, or help partners respond to romantic conflict in a constructive rather than destructive manner (cf. Abeyta et al., 2015). Finally, partners might turn to romantic nostalgia when feeling dissatisfied. Muise et al. (2020) reported that individuals nostalgize about sexual experiences in past relationships when their sexual needs in the current relationship are unmet. Although such sexual nostalgia does not seem to enhance 
(and may even hinder) sexual or relationship satisfaction, nostalgia for sex with one's current romantic partner may revitalize one's sexual life and enhance relational benefits.

Our findings have applied implications. Most notably, romantic nostalgia could be harnessed in a therapeutic setting to manage relationship woes. For example, when the bond between romantic partners cracks and relationship dissatisfaction sets in, one's well-being will inevitably suffer. Rather than ruminating on relationship dissatisfaction (Jostmann et al., 2011), our work suggests that nostalgizing about the relationship entails the potential to restore perceptions of relationship quality. Indeed, individuals experiencing relationship dysfunction might derive the greatest benefit from romantic nostalgia. The current studies provide empirical support for the utility of romantic nostalgia as a resource for healthy relationship functioning. Assuming replication and extension of our findings, relationship and marital counselors might be encouraged to incorporate romantic nostalgia as a tool for re-instating relationship functioning. By building on the ensuing literature, nostalgia and relationship researchers may foster a new means of approaching relationship conflict in a therapeutic setting.

\section{Limitations and Future Directions}

The studies in which we experimentally induced romantic nostalgia through writing (Study 2) and music (Study 3) provide causal evidence for the effect of romantic nostalgia on perceptions of relationship quality. However, our findings do not rule out the possibility that the direction of causality could also run in the opposite direction. That is, greater relationship quality could cause people to be more nostalgia about their relationship. In turn, romantic nostalgia, as we have shown, should then further increase perceptions of relationship quality, resulting in a cyclical pattern. Future work should investigate this possibility. 
Prior research has shown that thoughts about negative experiences in one's relationship are associated with unfavorable perceptions of one's relationship (Fincham \& Linfield, 1997; Fincham \& Rogge, 2010; Mattson et al., 2013). In light of the present research, however, reflecting on negative relationship experiences nostalgically may not produce such unfavorable consequences. As previously mentioned, nostalgic memories are largely, but not wholly, positive. Some nostalgic narratives contain negative past experiences. However, when they do contain negative experiences, they typically follow a redemptive sequence wherein an individual reflects on overcoming adversity or personal growth (Wildschut et al., 2006). For example, if a person nostalgically recalls a time when they had a fight with their partner, they would likely reframe it as surviving through adversity. Future research should examine this possibility.

Our studies focused on one partner's perceptions of relationship quality, and more specifically relational closeness, satisfaction, commitment, and love. Although such perceptions are key components of relationship quality, and arguably the most valid indicator for that individual (Fletcher et al., 2000), they form only part of the story of relationship functioning. Future research ought to examine additional processes such as support, conflict, accommodation, and forgiveness, and additional measures such as partner perceptions, coded couple behaviors, and breakup rates in order to ascertain the reach of romantic nostalgia.

We mentioned the therapeutic potential for romantic nostalgia to address and tackle relationship woes. However, to lay the groundwork for this, future research needs to take several steps. First, participants in our studies were generally satisfied with their relationships (i.e., they consistently scored above the midpoint on our outcome measures). It is thus possible that the benefits of romantic nostalgia only ensue when relationship satisfaction is relatively high. Future research should seek to replicate our findings among those with below average relationship 
satisfaction. Second, we assessed positive indicators of relationship quality. However, in a therapeutic context, romantic partners are likely to engage in reparative behaviors such as sacrifice, accommodation, and forgiveness. Assessing these outcomes in the future would provide a more comprehensive understanding of romantic nostalgia's utility as a therapeutic resource. Third, our studies examined the short-term benefits of romantic nostalgia. That is, we briefly induced romantic nostalgia and then immediately measured relationship outcomes. If romantic nostalgia is to be implemented in therapeutic settings, researchers need to develop and test romantic nostalgia interventions that produce long-term benefits. Fourth, we only induced romantic nostalgia in one partner. However, therapeutic interventions will often involve both partners. Prior work investigating collaborative remembering between romantic partners provides some preliminary evidence that points toward the potential for co-nostalgizing to serve relationship benefits. For example, romantic dyads co-reminiscing on shared laughter experiences report higher levels of relationship satisfaction relative to control romantic dyads (Bazzini et al., 2007). Therefore, future work could building on these findings to examine how partners' co-nostalgizing in conversation (cf. Dodd et al., 2021) influences their relationship. Additionally, a promising direction for future research is to test how attachment orientations shape the effects of romantic nostalgia. Attachment avoidance moderates how general nostalgia serves its social-oriented function. That is, participants low in avoidant attachment are particularly likely to rely on nostalgia to garner social connectedness when feeling lonely (Abakoumkin et al., 2017; Wildschut et al., 2010). More relevant to the current article, Juhl et al. (2012) found that, when experiencing general nostalgia, those low (vs. high) in attachment avoidance reported higher relationship satisfaction. Individuals low in attachment 
avoidance, then, may be most likely to leverage romantic nostalgia in order to reap its relational benefits.

Finally, for three of our four studies (Studies 2-4), we recruited college students. Future research should seek to use samples that are more representative of the general population. Relatedly, in these three studies, participants had been in their relationships for a relatively short time. Attaining samples more representative of the general population will enable researchers to capture the effects of romantic nostalgia in longer-term relationships. Similarly, we did not assess several participant characteristic variables, such as class, socioeconomic status, or disability information. Although we had no theoretical rationale as to how these variables might affect our findings, future research on romantic nostalgia would nevertheless benefit from measuring these demographics.

\section{Conclusion}

In four methodologically diverse studies, we took steps to lift the shroud of uncertainty that has so far obscured the role of romantic nostalgia in relational context. Our findings documented the multifaceted benefits of romantic nostalgia for relationship functioning in both laboratory and naturalistic settings. We hope that this work inspires efforts to understand and harness this powerful resource for restoring, maintaining, and enhancing romantic relationships. 


\section{References}

Abakoumkin, G., Wildschut, T., Sedikides, C., \& Bakarou, M. (2017). Nostalgia in response to group-based exclusion: The role of attachment-related avoidance. European Journal of Social Psychology, 47(3), 373-381. https://doi.org/10.1002/ejsp.2235

Abeyta, A. A., Routledge, C., \& Juhl, J. (2015). Looking back to move forward: Nostalgia as a psychological resource for promoting relationship goals and overcoming relationship challenges. Journal of Personality and Social Psychology, 109(6), 1029-1044. https://doi.org/10.1037/pspi0000036

Acevedo, B. P., \& Aron, A. (2009). Does a long-term relationship kill romantic love? Review of General Psychology, 13(1), 59-65. https://doi.org/10.1037/a0014226

Alea, N., \& Bluck, S. (2007). I'll keep you in mind: The intimacy function of autobiographical memory. Applied Cognitive Psychology, 21(1), 1091-1111. https://doi.org/10.1002/acp.1316

Alea, N., Singer, J. A., \& Labunko, B. (2015). "We-ness" in relationship-defining memories and marital satisfaction. In K. Skerrett \& K. Fergus (Eds.), Couple resilience (162-177). Springer.

Alea, N., \& Vick, S. C. (2010). The first sight of love: Relationship-defining memories and marital satisfaction across adulthood. Memory, 18(7), 730-742. https://doi.org/10.1080/09658211.2010.506443

Algoe, S. B., Gable, S. L., \& Maisel, N. C. (2010). It's the little things: Everyday gratitude as a booster shot for romantic relationships. Personal Relationships, 17(2010), 217-233. https://doi.org/10.1111/j.1475-6811.2010.01273.x 
Aron, A., Aron, E. N., \& Smollan, D. (1992). Inclusion of other in the self scale and the structure of interpersonal closeness. Journal of Personality and Social Psychology, 63(4), 596-612. https://doi.org/10.1037/0022-3514.63.4.596

Aron, A., Melinat, D., Aron, E. N., Vallone, R. D., \& Bator, R. J. (1997). The experimental generation of interpersonal closeness: A procedure and some preliminary findings. Personality and Social Psychology Bulletin, 23(4), 363-377. https://doi.org/10.1177/0146167297234003

Aron, A., Paris, M., \& Aron, E. N. (1995). Falling in love: Prospective studies of self-concept change. Journal of Personality and Social Psychology, 69(6), 1102-1112. https://doi.org/10.1037/0022-3514.69.6.1102

Arriaga, X. B., \& Agnew, C. R. (2001). Being committed: Affective, cognitive, and conative components of relationship commitment. Personality and Social Psychology Bulletin, 27(9), 1190-1203. https://doi.org/10.1177/0146167201279011

Barr, D. J., Levy, R., Scheepers, C., \& Tily, H. J. (2013). Random effects structure for confirmatory hypothesis testing: Keep it maximal. Journal of Memory and Language, 68(3), 255-278. https://doi.org/10.1016/j.jml.2012.11.001

Barrett, F. S., Grimm, K. J., Robins, R. W., Wildschut, T., Sedikides, C., \& Janata, P. (2010). Music-evoked nostalgia: Affect, memory, and personality. Emotion, 10(3), 390-403. https://doi.org/10.1037/a0019006

Baumeister, R. F., \& Leary, M. R. (1995). The need to belong: Desire for interpersonal attachments as a fundamental human motivation. Psychological Bulletin, 117(3), 497529. https://doi.org/10.1037/0033-2909.117.3.497 
Bazzini, D. G., Stack, E. R., Martincin, P. D., \& Davis, C. P. (2007). The effect of reminiscing about laughter on relationship satisfaction. Motivation and Emotion, 31, 25-34. https://doi.org/10.1007/s11031-006-9045-6

Biskas, M., Juhl, J., Wildschut, T., Sedikides, C., \& Saroglou, V. (2021). Nostalgia and spirituality: The roles of self-continuity and meaning in life. Manuscript under review, University of Sheffield, UK.

Braithwaite, S. R., Delevi, R., \& Fincham, F. D. (2010). Romantic relationships and the physical and mental health of college students. Personal Relationships, 17(1), 1-12. https://doi.org/10.1111/j.1475-6811.2010.01248.x

Bucher, A., Neubauer, A. B., Voss, A., \& Oetzbach, C. (2019). Together is better: Higher committed relationships increase life satisfaction and reduce loneliness. Journal of Happiness Studies, 20, 2445-2469. https://doi.org/10.1007/s10902-018-0057-1

Cheung, W. Y., Wildschut, T., Sedikides, C., Hepper, E. G., Arndt, J., \& Vingerhoets, A. J. J. M. (2013). Back to the future: Nostalgia increases optimism. Personality and Social Psychology Bulletin, 39(11), 1484-1496. https://doi.org/10.1177/0146167213499187

Cortes, K., Leith, S., \& Wilson, A. (2018). Relationship satisfaction and the subjective distance of past relational events. Journal of Social and Personal Relationships, 35(8), 1092-1117. https://doi.org/10.1177/0265407517704721

Cramer, D. (2004). Emotional support, conflict, depression, and relationship satisfaction in a romantic partner. The Journal of Psychology, 138(6), 532-542. https://doi.org/10.3200/JRLP.138.6.532-542 
Cramer, D., \& Jowett, S. (2010). Perceived empathy, accurate empathy and relationship satisfaction in heterosexual couples. Journal of Social and Personal Relationships, 27(3), 327-349. https://doi.org/10.1177/0265407509348384

Davis, M. H., \& Oathout, H. A. (1987). Maintenance of satisfaction in romantic relationships: Empathy and relational competence. Journal of Personality and Social Psychology, 53(2), 397-410. https://doi.org/10.1037/0022-3514.53.2.397

Dibble, J. L., Levine, T. R., \& Park, H. S. (2012). The Unidimensional Relationship Closeness Scale (URCS): Reliability and validity evidence for a new measure of relationship closeness. Psychological Assessment, 24(3), 565-572. https://doi.org/10.1037/a0026265

Dodd, E., Ismail, S., Christopher, G., Wildschut, T., Sedikides, C., \& Cheston, R. (2021). Nostalgic conversations: The co-production of an intervention package for people living with dementia and their spouse. Dementia: The International Journal of Social Research and Practice. Advance online publication. https://doi.org/10.1177/14713012211047350

Drivdahl, S. B. \& Hyman Jr., I. E. (2014). Fluidity in autobiographical memories: Relationship memories sampled on two occasions. Memory, 22(8). 1071-1080. https://doi.org/10.1080/09658211.2013.866683

Dunlop, W. L. (2019). Love as story, love as storytelling. Personal Relationships, 26, 114-136. https://doi.org/10.1111/pere.12271

Dunlop, W. L., Bühler, J., Maghsoodi, A., Harake, N., Wilkinson, D., \& McAdams, D. P. (2020). The stories couples live by. Journal of Social and Personal Relationships. Advance online publication. https://doi.org/10.1177/0265407520969900 
Enders, C. K., \& Tofighi, D. (2007). Centering predictor variables in cross-sectional multilevel models: A new look at an old issue. Psychological Methods, 12(2), 121-138. https://doi.org/10.1037/1082-989X.12.2.121

Evans, N. D., Reyes, J., Wildschut, T., Sedikides, C., \& Fetterman, A. K. (2021). Mental transportation mediates nostalgia’s psychological benefits. Cognition and Emotion, 35(1), 84-95. https://doi.org/10.1080/02699931.2020.1806788

Faul, F., Erdfelder, E., Buchner, A., \& Lang, A. G. (2013). Statistical power analyses using G* Power 3.1: Tests for correlation and regression analyses. Behavior Research Methods, 41(4), 1149-1160. https://doi.org/10.3758/BRM.41.4.1149

Fehr, B., Harasymchuk, C., \& Sprecher, S. (2014). Compassionate love in romantic relationships: A review and some new findings. Journal of Social and Personal Relationships, 31(5), 575-600. https://doi.org/10.1177/0265407514533768

Fetterman, A. K., Wilkowski, B. M., \& Robinson, M. D. (2018). On feeling warm and being warm: Daily perceptions of physical warmth fluctuate with interpersonal warmth. Social Psychological and Personality Science, 9(5), 560-567. https://doi.org/10.1177/1948550617712032

Fincham, F. D., \& Linfield, K. J. (1997). A new look at marital quality: Can spouses feel positive and negative about their marriage? Journal of Family Psychology, 11(4), 489502. https://doi.org/10.1037/0893-3200.11.4.489-502

Fincham, F. D., \& Rogge, R. D. (2010). Understanding relationship quality: Theoretical challenges and new tools for assessment. Journal of Family Theory and Review, 2(4), 227-242. https://doi.org/10.1111/j.1756-2589.2010.00059.x 
Fletcher, G. J., Simpson, J. A., \& Thomas, G. (2000). The measurement of perceived relationship quality components: A confirmatory factor analytic approach. Personality and Social Psychology Bulletin, 26(3), 340-354. https://doi.org/10.1177/0146167200265007

Frankenbach, J., Wildschut, T., Juhl, J., \& Sedikides, C. (2021). Does neuroticism disrupt the psychological benefits of nostalgia? A meta-analytic test. European Journal of Personality, 35(2), 249-266. https://doi.org/10.1080/10.1002/per.2276

Franzoi, S. L., Davis, M. H., Young, R. D. (1985). The effects of private self-consciousness and perspective taking on satisfaction in close relationships. Journal of Personality and Social Psychology, 48(6), 1584-1594. https://doi.org/10.1037/0022-3514.48.6.1584

Frost, D. M. (2013). The narrative construction of intimacy and affect in relationship stories: Implications for relationship quality, stability, and mental health. Journal of Social and Personal Relationships, 30(3), 247-269. https://doi.org/10.1177/0265407512454463

Gordon, A. M., Impett, E. A., Kogan, A., Oveis, C., \& Keltner, D. (2012). To have and to hold: Gratitude promotes relationship maintenance in intimate bonds. Journal of Personality and Social Psychology, 103(2), 257-274. https://doi.org/10.1037/a0028723

Guilbault, V., \& Philippe, F. L. (2017). Commitment in romantic relationships as a function of partners' encoding of couple-related memories. Memory, 25(5), 595-606. https://doi.org/10.1080/09658211.2016.1197943

Gulledge, A. K., Gulledge, M. H., \& Stahmann, R. F. (2003). Romantic physical affection types and relationship satisfaction. The American Journal of Family Therapy, 31(4), 233-242. https://doi.org/10.1080/01926180390201936

Hatfield, E., \& Sprecher, S. (1986). Measuring passionate love in intimate relationships. Journal of Adolescence, 9(4), 383-410. https://doi.org/10.1016/S0140-1971(86)80043-4 
Hatfield, E., \& Walster, G. W. (1978). A new look at love. University Press of America

Hendrick, C., \& Hendrick (1986). A theory and method of love. Journal of Personality and Social Psychology, 50(2), 392-402. https://doi.org/10.1037/0022-3514.50.2.392

Hepper, E. G., Ritchie, T. D., Sedikides, C., \& Wildschut, T. (2012). Odyssey’s end: Lay conceptions of nostalgia reflect its original Homeric meaning. Emotion, 12(1), 102-119. https://doi.org/10.1037/a0025167

Hepper, E. G., Wildschut, T., Sedikides, C., Ritchie, T. D., Yung, Y.-F., Hansen, N., Abakoumkin, G., Arikan, G., Cisek, S. Z., Demassosso, D. B., Gebauer, J. E., Gerber, J. P., González, R., Kusumi, T., Misra, G., Rusu, M., Ryan, O., Stephan, E., Vingerhoets, A. J. J. M., \& Zhou, X. (2014). Pancultural nostalgia: Prototypical conceptions across cultures. Emotion, 14(4), 733-747. https://doi.org/10.1037/a0036790

Hepper, E. G., Wildschut, T., Sedikides, C., Robertson, S., \& Routledge, C. D. (2021). Time capsule: Nostalgia shields psychological wellbeing from limited time horizons. Emotion, 21(3), 644-664. https://doi.org/10.1037/emo0000728

Jostmann, N. B., Karremans, J., \& Finkenauer, C. (2011). When love is not blind: Rumination impairs affect regulation in response to romantic relationship threat. Cognition and Emotion, 25(3), 506-518. https://doi.org/10.1080/02699931.2010.541139

Juhl, J., Routledge, C., Arndt, J., Sedikides, C., \& Wildschut, T. (2010). Fighting the future with the past: Nostalgia buffers existential threat. Journal of Research in Personality, 44(3), 309-314. https://doi.org/10.1016/j.jrp.2010.02.006

Juhl, J., Sand, E. C., \& Routledge, C. (2012). The effects of nostalgia and avoidant attachment on relationship satisfaction and romantic motives. Journal of Social and Personal Relationships, 29(5), 661-670. https://doi.org/10.1177/0265407512443433 
Juhl, J., Wildschut, T., Sedikides, C., Diebel, T., Cheung, W. Y., \& Vingerhoets, A. J. J. M. (2020). Nostalgia proneness and empathy: Generality, underlying mechanism, and implications for prosocial behavior. Journal of Personality, 88(3), 485-500. https://doi.org/10.1111/jopy.12505

Juhl, J., Wildschut, T., Sedikides, C., Xiong, X., \& Zhou, X. (2021). Nostalgia promotes help seeking by fostering social connectedness. Emotion, 21(3), 631-643. https://doi.org/10.1037/emo0000720

Karremans, J. C., \& Van Lange, P. A. M. (2004). Back to caring after being hurt: The role of forgiveness. European Journal of Social Psychology, 34(1), 207-227. https://doi.org/10.1002/ejsp.192

Kito, M. (2005). Self-disclosure in romantic relationships and friendships among American and Japanese college students. The Journal of Social Psychology, 145(2), 127-140. https://doi.org/10.3200/SOCP.145.2.127-140

Koelsch, S. (2013). Striking a chord in the brain: Neurophysiological correlates of music-evoked positive emotions. In T. Cochrane, B. Fantini, \& K. R. Sherer (Eds.), Series in affective science. The emotional power of music: Multidisciplinary perspectives on musical arousal, expression, and social control (pp. 227-249). Oxford University Press. https://doi.org/10.1093/acprof:oso/9780199654888.003.0017

Layous, K., Kurtz, J. L., Wildschut, T., \& Sedikides, C. (2021). The effect of a multi-week nostalgia intervention on well-being: Mechanisms and moderation. Emotion. Advance online publication. https://doi.org/10.1037/emo0000817 
Lemieux, R., \& Hale, J. L. (1999). Intimacy, passion, and commitment in young romantic relationships: Successfully measuring the triangular theory of love. Psychological Reports, 85(2), 497-503. https://doi.org/10.2466/pr0.1999.85.2.497

Lenton, A. P., Slabu, L., \& Sedikides, C. (2016). State authenticity in everyday life. European Journal of Personality, 30(1), 64-82. https://doi.org/10.1002/per.2033

Leunissen, J. M., Wildschut, T., Sedikides, C., \& Routledge, C. (2021). The hedonic character of nostalgia: An integrative data analysis. Emotion Review, 13(2), 139-156. https://doi.org/10.1177/1754073920950455

Madoglou, A., Gkinopoulos, T., Xanthopoulos, P., \& Kalamaras, D. (2017). Representations of autobiographical nostalgic memories: Generational effect, gender, nostalgia proneness and communication of nostalgic experiences. Journal of Integrated Social Sciences, 7, $60-88$.

Mallory, A. B., Spencer, C. M., Kimmes, J. G., \& Pollitt, A. M. (2018). Remembering the good times: The influence of relationship nostalgia on relationship satisfaction across time. Journal of Marital and Family Therapy, 44(4), 561-574. https://doi.org/10.1111/jmft.12311

Mattingly, B. A., McIntyre, K. P., \& Lewandowski, G. W. (2020). Relationship-induced selfconcept change: Theoretical perspectives and methodological approaches. In B. A. Mattingly, K. P. McIntyre, \& G. W. Lewandowski (Eds.), Interpersonal relationships and the self-concept (pp. 1-19). Springer. https://doi.org/10.1007/978-3-030-43747-3_1

Mattson, R. E., Rogge, R. D., Johnson, M. D., Davidson, E. K. B., \& Fincham, F. D. (2013). The positive and negative semantic dimensions of relationship satisfaction. Personal Relationships, 20(2), 328-355. https://doi.org/10.1111/j.1475-6811.2012.01412.x 
Maxwell, G. M. (1985). Behaviour of lovers: Measuring closeness of relationships. Journal of Social and Personal Relationships, 2(2), 215-238. https://doi.org/10.1177/0265407585022007

McAdams, D. P. (1996). Personality, modernity, and the storied self: A contemporary framework for studying persons. Psychological Inquiry, 7(4), 295-321. https://doi.org/10.1207/s15327965pli0704_1

McAdams, D. P., Reynolds, J., Lewis, M., Patten, A. H., \& Bowman, P. J. (2001). When bad things turn good and good things turn bad: Sequences of redemption and contamination in life narratives and their relation to psychosocial adaptation in midlife adults and in students. Personality and Social Psychology Bulletin, 27(4), 474-485. https://doi.org/10.1177/0146167201274008

Muise, A., Kim, J. J., Debrot, A., Impett, E. A., \& MacDonald, G. (2020). Sexual nostalgia as a response to unmet sexual and relational needs: The role of attachment avoidance. Personality and Social Psychology Bulletin, 46(11), 1538-1552. https://doi.org/10.1177/0146167220907468

Murray, A. J., \& Hazelwood, Z. J. (2011). Being grateful: Does it bring us closer? Gratitude, attachment and intimacy in romantic relationships. Journal of Relationships Research, 2(1), 17-25. https://doi.org/10.1375/jrr.2.1.17

Neto, F. (2021). Estimates about love for self, romantic partners, and parents. Marriage \& Family Review, 57(2), 111-125. https://doi.org/10.1080/01494929.2020.1740371

Neto, F. \& Wilks, D. C. (2017). Compassionate love for a romantic partner across the adult life span. Europe's Journal of Psychology, 13(4), 606-617. https://doi.org/10.5964/ejop.v13i4.1204 
Ohly, S., Sonnentag, S., Niessen, C., \& Zapf, D. (2010). Diary studies in organizational research: An introduction and some practical recommendations. Journal of Personnel Psychology, 9(2), 79-93. https://doi.org/10.1027/1866-5888/a000009

Pinheiro, J., Bates, D., DebRoy, S., Sarkar, D., \& R Core Team (2020). nlme: Linear and nonlinear mixed effects models. R package version 3.1-148, https://CRAN.Rproject.org/package $=$ nlme.

Raudenbush, S. W., \& Bryk, A. S. (2002). Hierarchical linear models: Applications and data analysis methods (Vol. 1). Sage.

Routledge, C., Arndt, J., Wildschut, T., Sedikides, C., Hart, C. M., Juhl, J., Vingerhoets, A. J. J. M., \& Schlotz, W. (2011). The past makes the present meaningful: Nostalgia as an existential resource. Journal of Personality and Social Psychology, 101(3), 638652. https://doi.org/10.1037/a0024292

Routledge, C., Wildschut, T., Sedikides, C., \& Juhl, J. (2013). Nostalgia as a resource for psychological health and well-being. Social and Personality Psychology Compass, 7(11), 808-818. https://doi.org/10.1111/spc3.12070

Rusbult, C. E. (1980). Commitment and satisfaction in romantic associations: A test of the investment model. Journal of Experimental Social Psychology, 16(2) 172-186. https://doi.org/10.1016/0022-1031(80)90007-4

Rusbult, C. E. (1983). A longitudinal test of the investment model: The development (and deterioration) of satisfaction and commitment in heterosexual involvements. Journal of Personality and Social Psychology, 45(1), 101-117. https://doi.org/10.1037/0022$\underline{3514.45 .1 .101}$ 
Rusbult, C. E., \& Buunk, B. P. (1993). Commitment processes in close relationships: An interdependence analysis. Journal of Social and Personal Relationships, 10(2), 175-204. https://doi.org/10.1177/026540759301000202

Rusbult, C. E., Hannon, P. A., Stocker, S. L., \& Finkel, E. J. (2005). Forgiveness and relational repair. In E. L. Worthington Jr. (Ed.), Handbook offorgiveness (pp. 185-205). Routledge.

Rusbult, C. E., Martz, J. M., \& Agnew, C. R. (1998). The investment model scale: Measuring commitment level, satisfaction level, quality of alternatives, and investment size. Personal Relationships, 5(4), 357-391. https://doi.org/10.1111/j.14756811.1998.tb00177.x

Schönbrodt, F. D., \& Perugini, M. (2013). At what sample size do correlations stabilize? Journal of Research in Personality, 47(1), 609-612. https://doi.org/10.1016/j.jrp.2013.05.009

Schröder-Abé, M., \& Schütz, A. (2011). Walking in each other's shoes: Perspective taking mediates effects of emotional intelligence on relationship quality. European Journal of Personality, 25(2), 155-169. https://doi.org/10.1002/per.818

Sedikides, C., Campbell, W. K., Reeder, G. D., \& Elliot, A. J. (1999). The relationship closeness induction task. Representative Research in Social Psychology, 23, 1-4.

Sedikides, C., Oliver, M. B., \& Campbell, W. K. (1994). Perceived benefits and costs of romantic relationships for women and men: Implications for exchange theory. Personal Relationships, 1(1), 5-21. https://doi.org/10.1111/j.1475-6811.1994.tb00052.x

Sedikides, C., \& Wildschut, T. (2016). Nostalgia: A bittersweet emotion that confers psychological health benefits. In A. M. Wood \& J. Johnson (Eds.), Wiley handbook of positive clinical psychology (pp. 25-36). Wiley. 
Sedikides, C., \& Wildschut, T. (2018). Finding meaning in nostalgia. Review of General Psychology, 22(1), 48-61. https://doi.org/10.1037/gpr0000109

Sedikides C., \& Wildschut, T. (2019). The sociality of personal and collective nostalgia. European Review of Social Psychology, 30(1), 123-173. https://doi.org/10.1080/10463283.2019.1630098

Sedikides, C., Wildschut, T., Cheung, W.-Y., Routledge, C., Hepper, E. G., Arndt, J., Vail, K., Zhou, X., Brackstone, K., \& Vingerhoets, A. J. J. M. (2016). Nostalgia fosters selfcontinuity: Uncovering the mechanism (social connectedness) and the consequence (eudaimonic well-being). Emotion, 16(4), 524-539. https://doi.org/10.1037/emo0000136

Sedikides, C., Wildschut, T., Routledge, C., Arndt, J., Hepper, E. G., \& Zhou, X. (2015). To nostalgize: Mixing memory with affect and desire. Advances in Experimental Social Psychology, 51, 189-273. https://doi.org/10.1016/bs.aesp.2014.10.001

Sedikides, C., Wildschut, T., \& Stephan, E. (2018). Nostalgia shapes and potentiates the future. In J. P. Forgas \& R. F. Baumeister (Eds.), The social psychology of living well (pp. 181199). Routledge.

Simpson, J. A., \& Campbell, L. (Eds.) (2013). The Oxford handbook of close relationships. Oxford University Press.

Sprecher, S., \& Fehr, B. (2005). Compassionate love for close others and humanity. Journal of Social and Personal Relationships, 22(5), 629-651. https://doi.org/10.1177/0265407505056439

Stephan, E., Sedikides, C., Wildschut, T., Cheung, W. Y., Routledge, C., \& Arndt, J. (2015). Nostalgia-evoked inspiration: Mediating mechanisms and motivational implications. 
Personality and Social Psychology Bulletin, 41(10), 1395-1410. https://doi.org/10.1177/0146167215596985

Steiger, J. H. (2004). Beyond the F test: Effect size confidence intervals and tests of close fit in the analysis of variance and contrast analysis. Psychological Methods, 9(2), 164-182. https://doi.org/10.1037/1082-989X.9.2.164

Sternberg, R. J., \& Grajek, S. (1984). The nature of love. Journal of Personality and Social Psychology, 47(2), 312-329. https://doi.org/10.1037/0022-3514.47.2.312

The New Oxford Dictionary of English. (1998). (J. Pearsall, Ed.). Oxford University Press.

Van Tilburg, W. A. P., Wildschut, T., \& Sedikides, C. (2018). Nostalgia’s place among selfrelevant emotions. Cognition and Emotion, 32(4), 742-759. https://doi.org/10.1080/02699931.2017.1351331

Van Tilburg, W. A. P., Bruder, M., Wildschut, T., Sedikides, C., \& Göritz, A. S. (2019). An appraisal profile of nostalgia. Emotion, 19(1), 21-36. https://doi.org/10.1037/emo0000417

Vess, M., Arndt, J., Routledge, C., Sedikides, C., \& Wildschut, T. (2012). Nostalgia as a resource for the self. Self and Identity, 11(3), 273-284. https://doi.org/10.1080/15298868.2010.521452

Wildschut, T., Bruder, M., Robertson, S., Van Tilburg, A. P. W., \& Sedikides, C. (2014). Collective nostalgia: A group-level emotion that confers unique benefits on the group. Journal of Personality and Social Psychology, 107(5), 844-863. https://doi.org/10.1037/a0037760 
Wildschut, T., \& Sedikides, C. (2022). Psychology and nostalgia: Towards a functional approach. In M. H. Jacobsen (Ed.), Intimations of nostalgia: Multidisciplinary explorations of an enduring emotion (pp. 110-128). Bristol University Press.

Wildschut, T., Sedikides, C., Arndt, J., \& Routledge, C. (2006). Nostalgia: Content, triggers, functions. Journal of Personality and Social Psychology, 91(5), 975-993. https://doi.org/10.1037/0022-3514.91.5.975

Wildschut, T., Sedikides, C., Routledge, C., Arndt, J., \& Cordaro, F. (2010). Nostalgia as a repository of social connectedness: The role of attachment-related avoidance. Journal of Personality and Social Psychology, 98(4), 573-586. https://doi.org/10.1037/a0017597

Zhou, X., Sedikides, C., Wildschut, T., Gao, D.-G. (2008). Counteracting loneliness: On the restorative function of nostalgia. Psychological Science, 19(10), 1023-1029. https://doi.org/10.1111/j.1467-9280.2008.02194.x 
Table 1

Correlations Between Romantic Nostalgia and Relational Benefits in

Study 1

\begin{tabular}{lcccc}
\hline \multicolumn{1}{c}{ Variable } & 1 & 2 & 3 & 4 \\
\hline 1. Romantic Nostalgia & - & & & \\
2. Closeness & $.23^{* * *}$ & - & & \\
3. Satisfaction & $.21^{* * *}$ & $.81^{* * *}$ & - & \\
4. Commitment & $.15^{*}$ & $.78^{* * *}$ & $.62^{* * *}$ & - \\
5. Relationship Length & -.06 & .06 & .02 & $.24^{* * *}$ \\
\hline Note: ${ }^{*} p<.05,{ }^{* *} p<.01,{ }^{* * *} p<.001$ & & &
\end{tabular}




\section{Table 2}

Effect of Romantic Nostalgia on Relational Benefits in Study 2

\begin{tabular}{|c|c|c|c|c|c|c|}
\hline \multirow[b]{2}{*}{ Feeling/Experience } & \multicolumn{2}{|c|}{ Condition $M(S D), n$} & \multirow[b]{2}{*}{$F$} & \multirow[b]{2}{*}{$\mathrm{df}$} & \multirow[b]{2}{*}{$\eta^{2}$} & \multirow[b]{2}{*}{$90 \% \mathrm{CI}$} \\
\hline & Nostalgia & Control & & & & \\
\hline 1. Closeness & $6.41(0.64), 54$ & $6.15(0.80), 76$ & 3.80 & 1,128 & .029 & $.000, .092$ \\
\hline 2. Satisfaction & $6.19(0.70), 57$ & $5.77(1.14), 76$ & $5.93^{*}$ & 1,131 & .043 & $.004, .113$ \\
\hline 3. Commitment & $6.23(0.87), 57$ & $5.77(1.00), 75$ & $7.89^{* *}$ & 1,130 & .057 & $.010, .133$ \\
\hline
\end{tabular}


Table 3

Correlations Among Relational Benefits and Relationship Duration in Study 3

\begin{tabular}{|c|c|c|c|c|c|c|c|}
\hline Variable & 1 & 2 & 3 & 4 & 5 & 6 & 7 \\
\hline 1. Connectedness & - & & & & & & \\
\hline 2. Optimism & $.90^{* * *}$ & - & & & & & \\
\hline 3. Closeness & $.27^{* *}$ & $.29^{* * *}$ & - & & & & \\
\hline 4. Satisfaction & $.32^{* * *}$ & $.31^{* * *}$ & $.67^{* * *}$ & - & & & \\
\hline 5. Commitment & .13 & $.17^{*}$ & $.67^{* * *}$ & $.61^{* * *}$ & - & & \\
\hline 6. Compassionate Love & $.26^{* *}$ & $.29^{* * *}$ & $.63^{* * *}$ & $.47^{* * *}$ & $.51^{* * *}$ & - & \\
\hline 7. Passionate Love & $.29^{* * *}$ & $.31^{* * *}$ & $.63^{* * *}$ & $.48^{* * *}$ & $.51^{* * *}$ & $.58^{* * *}$ & - \\
\hline 8. Relationship Duration & -.12 & $-.18^{*}$ & .00 & -.11 & .13 & -.01 & -.10 \\
\hline
\end{tabular}




\section{Table 4}

Effect of Romantic Nostalgia on Relational Benefits in Study 3

\begin{tabular}{|c|c|c|c|c|c|c|}
\hline \multirow[b]{2}{*}{ Feeling/Experience } & \multicolumn{2}{|c|}{ Condition $M(S D), n$} & \multirow[b]{2}{*}{$F$} & \multirow[b]{2}{*}{ df } & \multirow[b]{2}{*}{$\eta^{2}$} & \multirow[b]{2}{*}{$90 \% \mathrm{CI}$} \\
\hline & Nostalgia & Control & & & & \\
\hline 1. Connectedness & $91.19(14.19), 75$ & $31.16(29.99), 76$ & $246.03^{* * *}$ & 1,149 & .623 & $.548, .682$ \\
\hline 2. Optimism & $91.48(10.72), 75$ & $39.25(31.22), 75$ & $187.80^{* * *}$ & 1,148 & .559 & $.476, .627$ \\
\hline 3. Closeness & $90.63(10.31), 75$ & $85.45(13.75), 75$ & $6.805^{*}$ & 1,148 & .044 & $.006, .110$ \\
\hline 4. Satisfaction & $88.22(13.16), 75$ & 81.34(16.49), 76 & $8.01^{* *}$ & 1,149 & .051 & $.009, .119$ \\
\hline 5. Commitment & 90.69(11.94), 72 & 87.24(17.04), 75 & 2.00 & 1,145 & .014 & $.000, .061$ \\
\hline 6. Compassionate Love & $89.57(9.51), 75$ & 85.77(11.29), 76 & $5.018^{*}$ & 1,149 & .033 & $.002, .092$ \\
\hline 7. Passionate Love & $79.48(11.58), 75$ & $73.16(18.28), 76$ & $6.416^{*}$ & 1,149 & .041 & $.005, .105$ \\
\hline
\end{tabular}

Note: ${ }^{*} p<.05, * * p<.01, * * * p<.001$ 


\section{Table 5}

Multilevel Models Testing the Unique Association between Daily Romantic Nostalgia and Daily Relational Benefits in Study 4

\begin{tabular}{|c|c|c|c|c|c|c|c|c|}
\hline Model No. & Outcome & Predictor & $b$ & $S E$ & $t$ & $\mathrm{df}$ & $p$ & $95 \% \mathrm{CI}$ \\
\hline \multirow[t]{3}{*}{ Model 1} & Connectedness & Romantic Nostalgia & .229 & .031 & 7.33 & 925 & $<.001$ & $.168, .290$ \\
\hline & Optimism & Romantic Nostalgia & .141 & .029 & 4.82 & 925 & $<.001$ & $.084, .199$ \\
\hline & Desire to Leave & Romantic Nostalgia & -.089 & .026 & -3.44 & 925 & $<.001$ & $-.140 .-.038$ \\
\hline \multirow[t]{6}{*}{ Model 2} & Connectedness & Time Spent with Partner & .294 & .031 & 9.45 & 876 & $<.001$ & $.233, .355$ \\
\hline & & Romantic Nostalgia & .159 & .029 & 5.51 & 876 & $<.001$ & $.103, .216$ \\
\hline & Optimism & Time Spent with Partner & .147 & .029 & 4.99 & 876 & $<.001$ & $.089, .205$ \\
\hline & & Romantic Nostalgia & .109 & .030 & 3.63 & 876 & $<.001$ & $.050, .167$ \\
\hline & Desire to Leave & Time Spent with Partner & -.047 & .029 & -1.61 & 876 & .108 & $-.105, .010$ \\
\hline & & Romantic Nostalgia & -.086 & .025 & -3.46 & 876 & $<.001$ & $-.135,-.037$ \\
\hline
\end{tabular}

